\title{
Are Amyotrophic Lateral Sclerosis Caregivers at Higher Risk for Health Problems?
}

\author{
Estarão os Cuidadores de Doentes com Esclerose \\ Lateral Amiotrófica em Maior Risco de Desenvolver \\ Problemas de Saúde?
}

\author{
Ana Catarina PINHO $\triangle^{1}$, Edna GONÇALVES ${ }^{1,2}$ \\ Acta Med Port 2016 Jan;29(1):56-62

\section{ABSTRACT} \\ Introduction: Amyotrophic lateral sclerosis is a rare neurodegenerative disease affecting motor neurons. Patients present \\ with progressive physical impairment, respiratory failure being the main cause of death. A significant portion of patients presents \\ neurobehavioral problems as well. As severe impairment occurs, patients become highly dependent and in general, their families \\ assume the role of primary caregivers, exposing them to stress and other potential causes of disease like insomnia, physical strain from \\ patients' mobilization and changes on eating habits. The aim of this work is to understand if taking care of patients with amyotrophic \\ lateral sclerosis increases disease and health problems on caregivers.
}

Material and Methods: Comprehensive review of the literature published on the electronic databases PubMed and Scopus between 2010 and 2014.

Results: Eighteen studies met the inclusion criteria. We found that amyotrophic lateral sclerosis caregivers have higher levels of burden, depression and anxiety with lower quality of life. This is associated to age and gender of caregivers, time spent caring, patients' disability and neurobehavioral changes. Higher sense of support and spirituality on family seem to promote wellbeing.

Discussion: On our work, we were able to understand that several factors have influenced caregivers' quality of life and affect their health. Besides, we could understand that the outcomes studied are related between themselves and, as seen in some of the studies, related to patients' quality of life itself. Consequently, it has become essential to adopt a holistic approach of these patients and their families, fighting the deteriorating risk factors and investing on health promoters.

Conclusion: Despite the large body of research on family caregiving for amyotrophic lateral sclerosis patients, little has changed and the outcomes measured remain almost the same before and after 2010. The work indicates that caregivers have lower levels of health than the general population. Still additional research is required, in order to better understand and characterized the changes on caregivers' health. It is nevertheless clear that health care professionals cannot ignore these health changes and need an approach focused not only on patients but also on caregivers.

Keywords: Amyotrophic Lateral Sclerosis; Caregivers; Quality of Life.

\section{RESUMO}

Introdução: A esclerose lateral amiotrófica é uma doença neuro-degenerativa rara que afeta os neurónios motores. Os doentes apresentam-se com incapacidade motora progressiva e, por vezes, alterações neuro-comportamentais e a principal causa de morte é a falência respiratória. Com o agravamento da incapacidade funcional, os pacientes tornam-se altamente dependentes da família, que assume o papel de cuidador primário, expondo-se ao stress e outras potenciais causas de doença como insónias, o esforço físico realizado para a mobilização dos pacientes e alterações nos hábitos alimentares. O principal objetivo do nosso trabalho é perceber se cuidar de doentes com esclerose lateral amiotrófica aumenta os níveis de doença ou problemas de saúde nos cuidadores.

Material e Métodos: Através de uma revisão exaustiva, analisámos a bibliografia publicada nas bases de dados eletrónicas PubMed e Scopus entre 2010 e 2015.

Resultados: Verificámos que os cuidadores têm níveis mais elevados de sobrecarga, depressão e ansiedade, assim como menor qualidade de vida. Estes resultados relacionam-se com a idade e o género do cuidador e a duração dos cuidados, para além da incapacidade e das alterações neuro-comportamentais do doente. Uma elevada perceção de suporte e a espiritualidade do cuidador promovem o bem-estar.

Discussão: No nosso trabalho foi-nos possível perceber que diversos factores influenciam a qualidade de vida dos cuidadores e afetam a sua saúde. Para além disso, pudemos perceber também que os diversos parâmetros avaliados estão relacionados entre si e, como visto em alguns dos estudos, relacionados com a própria qualidade de vida dos doentes. Consequentemente, tornou-se essencial adotar uma abordagem holística destes pacientes e das suas famílias, combatendo os factores prejudiciais e investindo nos promotores da saúde.

Conclusão: Apesar de toda a investigação realizada sobre cuidadores de doentes com esclerose lateral amiotrófica, as variáveis analisadas antes e depois de 2010 foram praticamente as mesmas e pouco mudou nos últimos anos. Tendo sido previamente verificado que os cuidadores têm menores níveis de saúde que a população geral, ainda há muito a fazer no sentido de melhor caracterizar e compreender as alterações de saúde que ocorrem nos cuidadores de doentes com esclerose lateral amiotrófica. No entanto, desde já reforçar a ideia de que os profissionais de saúde não podem ignorar estes factos e devem focar a sua atenção nos pacientes e cuidadores.

Palavras-chave: Cuidador; Esclerose Lateral Amiotrófica; Qualidade de Vida.

1. Faculdade de Medicina. Universidade do Porto. Porto. Portugal.

2. Serviço de Cuidados Paliativos. Centro Hospitalar São João. Porto. Portugal.

$\bowtie$ Autor correspondente: Ana Catarina Pinho. mimed09199@med.up.pt

Recebido: 07 de maio de 2015 - Aceite: 27 de outubro de 2015 | Copyright @ $\odot$ Ordem dos Médicos 2016 


\section{INTRODUCTION}

Amyotrophic lateral sclerosis (ALS) is the most common motor neuron disease (MND) characterized by the progressive loss of the upper and lower motor neurons function without notable sensory symptoms. Idiopathic and fatal, about $5 \%-10 \%$ of ALS are familial and there is a genetic overlap with other progressive neurodegenerative syndromes such as front temporal dementia (FTD), with $20 \%-50 \%$ of ALS patients fulfilling the consensus criteria for probable or definite FTD. ${ }^{1-3}$

With a reported incidence varying between $0.3-2.5$ per 100000 persons per year, the mean age of onset for ALS varies between $58-63$ years for sporadic disease and 47 - 52 years for familial disease. It affects more commonly men than women ( 3 vs 2.4 per 100000 persons per year), although the number of women affected increases in older age groups. ${ }^{1,2,4}$

The course of the disease can vary from rapid to slow progression with $50 \%$ of patients dying within 30 months of symptom onset while approximately $20 \%$ of patients remain alive 5 - 10 years after the inaugural signs of the disease. ${ }^{2}$ Commonly, death is caused by respiratory arrest due to failure of respiratory musculature. ${ }^{4}$

The main presentations of ALS include a limb-onset form of the disease with a combination of upper and lower motor neuron signs $(70 \%)$, the bulbar-onset, presenting with speech and swallowing difficulties with limb features developing later in the course of the disease $(25 \%)$ and the initial trunk or respiratory involvement $(5 \%){ }^{2}$ Regardless the initial presentation, disease progression leads invariably to a state of major dependence on those responsible for

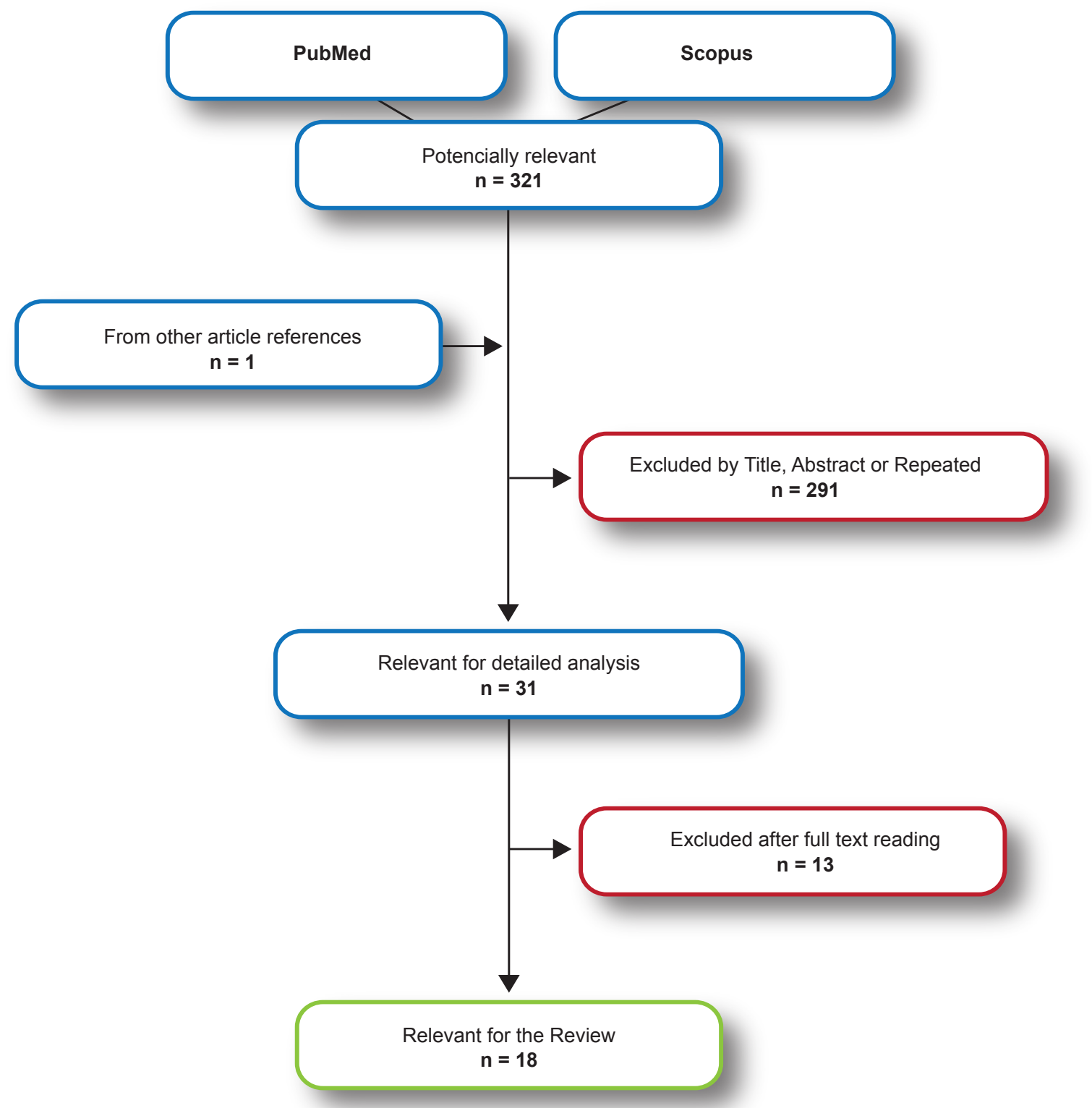

Figure 1 - Flowchart of selection process 
constant care of these patients out of the hospital, the socalled primary caregivers. ${ }^{5}$ Right from the start of ALS, they assume a central role in maintaining patient's quality of life (QoL) without any income or payment. ${ }^{3}$

In recent years, there has been growing interest in caregiver's health, mainly in neurodegenerative disorders, cancer and AIDS. Knowing the effects of caregiving on health and wellbeing can direct the development of practical and psychosocial support for caregivers, a potential clue also to improve patient care..$^{7-10}$

In 2012, Saoun et al published a 10-year literature review of family caregiving for MND, where the authors get to the conclusion that carers see their quality of life compromised by the role they play. They also light up the need to provide caregivers psychological to social support, in order to diminish the tension and all disastrous consequences that can come from their tasks. ${ }^{6}$

\section{Aim}

With the intention of updating and supplementing the knowledge built until now, we carried out a comprehensive review of the literature published in the last five years in order to understand if taking care of patients with ALS is truly relevant for caregivers' health, increasing their risk for disease. Furthermore, we tried to identify risk factors for caregiver's illness, which could lead to effective therapeutic and preventive interventions.

\section{MATERIAL AND METHODS}

A comprehensive review of the literature was made from indexed articles to the PubMed and Scopus databases from January 2010 until December 2014, written in English, Portuguese, Italian or Spanish.

Health is a state of complete physical, mental and social well-being and not merely the absence of disease or infirmity, as proposed by the World Health Organization. Therefore, we searched not only specific diseases on caregivers, like depression, but also some aspects that interfere with health related quality of life (HRQOL), from sleep disturbances to increased strain or stress, that are already proved to be related with lower levels of health. ${ }^{7}$

The search query was: ('caregivers'[MeSH Terms]) OR caregiver) OR family caregiver)) AND ('health'[MeSH Terms]) OR burden) OR disease) AND ('amyotrophic lateral sclerosis'[MeSH Terms]) OR ALS) OR motor neuron disease).

We considered 'caregiver' someone who is mainly responsible for everyday home care of patient without being paid or receive any income.

Review articles and studies including remunerate caregivers or health care professionals like doctors, nurses or paid caregivers were excluded.

We selected articles about any health or quality of life changes, like burden, distress, sleep disturbance, depression and anxiety.

Two independent evaluators made the selection of articles, initially by title and abstract and if there was any disagreement, the decision was made by consensus. The initial selection process was followed by the integral reading of the articles in order to select which articles fulfill the inclusion and exclusion criteria previously determined.

\section{RESULTS}

From the initial electronic research, we got 321 potentially relevant papers, 291 of which were excluded based on the title, abstract or because they were repeated. We decided to add one article from the other articles references.

After independent analyses of the 31 articles selected for detailed analysis, the two reviewers considered 18 papers relevant for answering the main goal of this work. All steps of the selection process are described on the flowchart (Fig. 1).

Of the 18 relevant studies, $15(83 \%)$ used quantitative analysis methods, one (6\%) used qualitative methods and two $(11 \%)$ mixed methods and the number of caregivers involved in each study varied from 29 to 434 . With the exception of one,$^{8}$ all studies included only ALS patient caregivers. Other features of the 18 papers selected are presented on Table 1.

\section{Caregiver burden}

As previously mentioned, caregiving for someone with ALS can be an important source of strain, not only psychologically but also physically since the dependence caused by the disease increases over time and consequently increases the demands on family. ${ }^{9,10}$

Some studies found that worsening of ALS with progression to impairment on mobility and respiratory failure needing ventilation have impact on caregiver's burden. ${ }^{10-13}$ Both NIV and mechanical ventilation cause high levels of anxiety and depression, ${ }^{14}$ increased strain, and low quality of life. ${ }^{11}$ The general impact of non-invasive ventilation (NIV) has a greater expression on caregivers' physical health than on their mental health. ${ }^{15}$

The behavior and personality changes that occur with some cases of ALS, varying from apathy and loss of awareness $^{16}$ to social boldness and abnormal behavior ${ }^{17}$ have been also described as important promoters of strain upon the family. Lillo et al ${ }^{18}$ findings also reinforced this idea noticing that modifications on patients' personality and behavior in the evolution of the disease cause an increase on caregiver's burden that is not seen with physical impairment. Other authors, like Chiò et al also observed the same. ${ }^{19}$

Other risk factors associated with greater strain were the carers' age and gender, with women, which represent the majority of caregivers, at higher risk. It seems relevant to refer the fact that, giving the time they spend on taking care of ALS patients, these people tend to ignore their own health condition, which could become a serious problem since older people have a higher risk of disease than younger ones. ${ }^{10,20}$

Oyebode et $\mathrm{al}^{12}$ got to the conclusion that caregiving assumes the main role in life of these people, leading to 
Table 1 - Papers' features

\begin{tabular}{|c|c|c|c|}
\hline \multicolumn{4}{|l|}{ Paper's features $(n=18)$} \\
\hline \multicolumn{4}{|l|}{ Country } \\
\hline Italy & 7 & Japan & 1 \\
\hline United Kingdom & 4 & Australia & 1 \\
\hline Sweden & 2 & China & 1 \\
\hline United States of America & 1 & South Korea & 1 \\
\hline \multicolumn{4}{|l|}{ Research themes } \\
\hline Caregiver burden & 13 & Distress & 2 \\
\hline Depression and anxiety & 11 & Intimacy problems & 1 \\
\hline Caregiver Quality of Life & 9 & Sleep disturbance & 1 \\
\hline \multicolumn{4}{|l|}{ Caregivers' mean age } \\
\hline$>60$ & & & 9 \\
\hline$<60$ & & & 7 \\
\hline Not Specified & & & 2 \\
\hline \multicolumn{4}{|l|}{ Relationship patient - caregiver } \\
\hline Family & & & 13 \\
\hline Friend & & & 3 \\
\hline Not Specified & & & 2 \\
\hline \multicolumn{4}{|l|}{ Number of caregivers included } \\
\hline$<50$ & & & 9 \\
\hline $50-100$ & & & 6 \\
\hline$>100$ & & & 3 \\
\hline \multicolumn{4}{|l|}{ Risk factors for health problems } \\
\hline Caregivers' age & 2 & Caregivers' support & 2 \\
\hline Caregivers' gender & 3 & Caregiver financial and educational level & 2 \\
\hline Functional impairment of patient & 6 & Neurobehavioral changes of patient & 2 \\
\hline Depression and anxiety on patient & 2 & Length of care & 3 \\
\hline Patients' breath problems & 1 & Spirituality & 2 \\
\hline
\end{tabular}

QoL: quality of life

a sense of exhaustion, frustration and anger. In addition to that, they have to deal with the constant loss of the cared one, changes in intimacy and the prolonged grief that accompanies a situation like the one they are living.

One aspect that decreased the burden and strain felt by family caregivers and friends was spirituality and religious beliefs, not only theirs but also from the patients. ${ }^{20,21}$

As expected, different authors demonstrated a negative correlation between the presence of spirituality and caregivers' stress, highlighting the need to create multidisciplinary teams including a spiritual adviser ${ }^{11,12,14,20,22,23}$

\section{Caregiver's depression and anxiety}

Other main determinant on caregiver's health that has been widely studied is the presence of depression and anxiety as a consequence of dealing with ALS on a family member. However, there's some disagreement between different authors on that topic. While some found that this group of people had higher levels of anxiety and depression than the comparative group, ${ }^{14,18,22,24}$ others found no difference on these parameters when comparing with the general population. ${ }^{25}$

We also found different and sometimes contradictory conclusions about the risk factors for developing depression and anxiety. Some authors proposed patients' cognitive and behavioral changes as determinants for the depressive symptoms in the family ${ }^{14,26}$ but not the worsening of physical function or severity of ALS. ${ }^{20,24}$ On the other hand, Pagnini et al considered the severity of the disease and worsening of the respiratory function as risk factors for complains of anxiety and depression on caregivers. ${ }^{22,27}$ It was additionally suggested that these severities could be translated in somatic symptoms of depression on caregiver's health more than psychological ones. ${ }^{22}$

Incongruence on results is also seen when we talk about the prevalence of depression and anxiety on caregivers compared to the ALS patients. Marconi et al ${ }^{14}$ refer a higher prevalence on caregivers while Chen ${ }^{24}$ sees higher levels on patients. Despite the lack of consensus, several authors found a correlation between patients' and caregivers' psychological changes, concluding that they are dependent on each other and so, ALS has significant impact on both members of the pair. ${ }^{14,24,26}$ 
Despite the more or less polemic risk factors enumerated above, some others became relevant as causes for the deterioration of mental health on carers. Age and female gender were once again cited as important causes, but this time the younger ( $<50$ years) were the ones at higher risk of suffering with caregiving. ${ }^{20}$ Social and economic support, religion (catholic and protestant), spirituality, and lower levels of caregiver's burden were associated with lower levels of caregivers' depression and anxiety. ${ }^{20-22,24}$ Invasive ventilation with tracheotomy was also associated with high levels of caregiver's anxiety and depression. ${ }^{14}$

\section{Caregiver's quality of life}

The third most reviewed topic of caregivers' health was quality of life (QoL), highlighting the health-related quality of life (HRQoL).

Several studies found that caregiving for patients with ALS is associated with worse QoL when compared with the general population. ${ }^{23,25,26}$ On his mixed method study, through qualitative interviews where caregivers were asked to talk about their worries, Pagnini et al found that carers expressed a major concern about their own physical health. ${ }^{22}$

Spirituality, less burden and strain $^{11}$ and a stronger perception of social support and assistance are among the factors that promote a better QoL. ${ }^{11,23,28}$ Olsson et al described a correlation between caregivers' and patients' QoL, although there was no association between patients' physical impairment and the emergence of changes in QoL. On the other hand, the later were connected to patient's neurobehavioral symptoms. ${ }^{19}$

One important factor associated with lower HRQoL was the use of ventilation on ALS patients. NIV and mechanical ventilation on tracheostomized patients decreased quality of life on family, since they become responsible for the maintenance of the equipment and stability of the patient that is in more advanced stages of the disease..$^{11,27}$ This impact was therefore stronger on physical health than mental health of carers. ${ }^{15}$

\section{Other health related topics}

In addition to the previously mentioned alterations, studies addressed other changes that could be involved on the appearance of disease on caregivers. For example, taking care of the consort proved to have impact on the relationship itself once it caused changes in intimacy or even the switch of roles between the two persons involved. ${ }^{12}$

\section{DISCUSSION}

The aim of this study was to understand if informal care of ALS patients is associated with particular disorders on the family/caregivers. As we didn't found any paper describing particular disorders we decided to update the 10-year literature review of family caregiving for MND published in 2012 by Aoun et $\mathrm{al}^{6}$ in order to draw attention to the need of better knowledge on caring the family members and other informal caregivers of ALS patients.
In agreement with the previous literature, recent literature continues warning to the fact that caregivers' wellbeing and health are impaired by the care. One of the three main explored areas was mental health, with higher levels of depression and anxiety in ALS carers that, even if not severe on the majority of cases, are higher than the general population. Other areas that interfere with health are the burden felt by caregivers that influence their physical and mental health as well as their QoL.

Depression and anxiety, burden and QoL were found to be interrelated. For example, higher levels of burden lead to more depressive symptoms and less quality of life, not only on parameters related to psychological but also to physical health.

Looking for risk factors that lowered health and harmed welfare of family the features associated with higher influence on it were advanced disease and its progression (usually assessed by the revised ALS functional rating scale - ALSFR-R), especially when breathing issues and the recourse of ventilator support become evident. Surprisingly, physical incapacity in itself wasn't always related with caregiver wellbeing. Besides, a higher number of hours per day spent caring, the lack of social support, information and lower incomes were also causes of more morbidity.

The association between female gender and older age with lower health levels is an important issue. Particular attention with this group of people is needed as the disease is more prevalent in men over 50 years old and in most cases their wives become the principal carers.

Meanwhile, there were also some protective factors, like spirituality and having a religious confession, which increased the wellbeing of those taking care of a family member with ALS.

Even if not consensual, the positive correlation between caregivers' and patients' depression and quality of life indicate that healthcare professionals also need to take care of the caregivers since any intervention to improve QoL of caregivers will have impact on the ALS patient. We found some limitations on studies analyzed. The first one was the small sample size, particularly on the first published studies most of them with less than 50 caregivers, making it hard to find some variability that would not compromise the results. Even so, larger samples explored closely the same outcomes. None of the samples was randomized, creating very homogeny between studies. As previously said, older women represent the majority of caregivers and some problems pointed could be explained based on gender and not on caregiving itself, like higher levels of depression seen in women rather than men. ${ }^{29}$ Another problem found was the different measures used in quantifying the different variables presented which can explain the disparities between results, with some studies with higher levels of morbidity than others.

Despite the fact that some new articles have been published between 2010 and 2014, we can see that the conclusions published by Samoun et al in $2012^{6}$ were similar to ours. This alerts us to the need of changing the 
way caregivers of ALS patients are treated. We should dedicate them a similar attention to the one we devote to patients themselves, including a personal assessment of their health problems and support to their doubts on how to care for their loved ones as the disease progresses. A possible intervention at this level would thus imply two visits to each ALS patient: one for the patient and another for the caregiver, with moments where both would be present.

Despite the large number of publications, there are still many questions to answer about the risks of caregiving. In fact, in other areas of care such as dementia or cancer, it was found that caregivers had higher risk of cardiovascular disease, ${ }^{30-32}$ an impaired immunity that could compromise healing ${ }^{33-36}$ and even a higher mortality than the general population, between older spouses. ${ }^{37}$ Since caregivers of ALS patients are subject to a large overhead and increased risk of depression and anxiety, this led us thinking that more studies need to be made to clarify such aspects.

\section{CONCLUSIONS}

Treating patients with ALS is a huge challenge for healthcare professionals. The absence of cure, its progressive character and the impact it has on patients and their caregivers turn ALS a disease with indication for palliative care (PC) from the time of diagnosis. Caregivers' health might be compromised by taking care of ALS patients. This is a problem not only for the family caregivers but also for the patients' own health. We believe that a patient/family centered approach in ALS, such as provided by PC specialists could be an effective way to empower caregivers, bringing great benefits to the pair and to the health system in general.

\section{CONFLICTS OF INTEREST}

The authors declare that there are no conflicts of interest.

\section{FUNDING SOURCES}

No subsidies or grants contributed to this work.

\section{REFERENCES}

1. Pratt AJ, Getzoff ED, Perry JJ. Amyotrophic lateral sclerosis: update and new developments. Degener Neurol Neuromuscul Dis. 2012;2012:1-14.

2. McDermott CJ, Shaw PJ. Diagnosis and management of motor neurone disease. BMJ. 2008;336:658-62.

3. Vitaliano PP, Zhang J, Scanlan JM. Is caregiving hazardous to one's physical health? A meta-analysis. Psychol Bull. 2003;129:946-72.

4. Kiernan MC, Vucic S, Cheah BC, Turner MR, Eisen A, Hardiman O, et al. Amyotrophic lateral sclerosis. Lancet. 2011;377:942-55.

5. Rothman AA, Wagner EH. Chronic illness management: what is the role of primary care? Ann Intern Med. 2003;138:256-61.

6. Aoun SM, Bentley B, Funk L, Toye C, Grande G, Stajduhar KJ. A 10year literature review of family caregiving for motor neurone disease: moving from caregiver burden studies to palliative care interventions. Palliat Med. 2013;27:437-46.

7. Bell CM, Araki SS, Neumann PJ. The association between caregiver burden and caregiver health-related quality of life in Alzheimer disease. Alzheimer Dis Assoc Disord. 2001;15:129-36.

8. Miyashita M, Narita Y, Sakamoto A, Kawada N, Akiyama M, Kayama M, et al. Health-related quality of life among community-dwelling patients with intractable neurological diseases and their caregivers in Japan. Psychiatr Clin Neurosci. 2011;65:30-8.

9. Elamin M, Bede P, Byrne S, Jordan N, Gallagher L, Wynne B, et al. Cognitive changes predict functional decline in ALS: a population-based longitudinal study. Neurology 2013;80:1590-7.

10. Tramonti F, Bongioanni P, Leotta R, Puppi I, Rossi B. Age, gender, kinship and caregiver burden in amyotrophic lateral sclerosis. Psychol Health Med. 2015;20:41-6.

11. Kim $\mathrm{CH}$, Kim MS. Ventilator use, respiratory problems, and caregiver well-being in korean patients with amyotrophic lateral sclerosis receiving home-based care. J Neurosci Nurs. 2014;46:E25-32.

12. Oyebode JR, Smith HJ, Morrison K. The personal experience of partners of individuals with motor neuron disease. Amyotroph Lateral Scler Frontotemporal Degener. 2013;14:39-43.

13. Bruletti G, Comini L, Scalvini S, Morini R, Luisa A, Paneroni M, et al. A two-year longitudinal study on strain and needs in caregivers of advanced ALS patients. Amyotroph Lateral Scler Frontotemporal Degener. 2015;16:187-95.

14. Marconi A, Meloni G, Fossati F, Lunetta C, Bastianello S, Melazzini M, et al. Aggressiveness, sexuality, and obsessiveness in late stages of ALS patients and their effects on caregivers. Amyotroph Lateral Scler. 2012;13:452-8.

15. Baxter SK, Baird WO, Thompson S, Bianchi SM, Walters SJ, Lee E, et al. The impact on the family carer of motor neurone disease and intervention with noninvasive ventilation. J Palliat Med. 2013;16:1602-9.

16. van der Hulst EJ, Bak TH, Abrahams S. Impaired affective and cognitive

theory of mind and behavioural change in amyotrophic lateral sclerosis. J Neurol Neurosurg Psychiatry. 2015;86:1208-15

17. Strong MJ, Grace GM, Freedman M, Lomen-Hoerth C, Woolley S, Goldstein LH, et al. Consensus criteria for the diagnosis of frontotemporal cognitive and behavioural syndromes in amyotrophic lateral sclerosis. Amyotroph Lateral Scler. 2009;10:131-46.

18. Lillo P, Mioshi E, Hodges JR. Caregiver burden in amyotrophic lateral sclerosis is more dependent on patients' behavioral changes than physical disability: a comparative study. BMC Neurol. 2012;12:156.

19. Chio A, Vignola A, Mastro E, Giudici AD, lazzolino B, Calvo A, et al. Neurobehavioral symptoms in ALS are negatively related to caregivers' burden and quality of life. Eur J Neurol. 2010;17:1298-303.

20. Qutub K, Lacomis D, Albert SM, Feingold E. Life factors affecting depression and burden in amyotrophic lateral sclerosis caregivers. Amyotroph Lateral Scler Frontotemporal Degener. 2014;15:292-7.

21. Pagnini F, Lunetta C, Rossi G, Banfi P, Gorni K, Cellotto N, et al. Existential well-being and spirituality of individuals with amyotrophic lateral sclerosis is related to psychological well-being of their caregivers. Amyotroph Lateral Scler. 2011;12:105-8.

22. Pagnini F, Rossi G, Lunetta C, Banfi P, Castelnuovo G, Corbo M, et al. Burden, depression, and anxiety in caregivers of people with amyotrophic lateral sclerosis. Psychol Health Med. 2010;15:685-93.

23. Peters M, Fitzpatrick R, Doll H, Playford ED, Jenkinson C. The impact of perceived lack of support provided by health and social care services to caregivers of people with motor neuron disease. Amyotroph Lateral Scler. 2012;13:223-8.

24. Chen D, Guo X, Zheng Z, Wei Q, Song W, Cao B, et al. Depression and anxiety in amyotrophic lateral sclerosis: Correlations between the distress of patients and caregivers. Muscle Nerve. 2015;51:353-7.

25. Ozanne AG, Strang S, Persson LI. Quality of life, anxiety and depression in ALS patients and their next of kin. J Clin Nurs. 2011;20:283-91.

26. Olsson AG, Markhede I, Strang S, Persson LI. Differences in quality of life modalities give rise to needs of individual support in patients with ALS and their next of kin. Palliat Support Care. 2010;8:75-82.

27. Pagnini F, Banfi P, Lunetta C, Rossi G, Castelnuovo G, Marconi A, et al. Respiratory function of people with amyotrophic lateral sclerosis and caregiver distress level: a correlational study. Biopsychosocial Med. 2012;6:14.

28. Peters M, Jenkinson C, Doll H, Playford ED, Fitzpatrick R. Carer quality of life and experiences of health services: a cross-sectional survey across three neurological conditions. Health Qual Life Outcomes. 2013;11:103

29. Kessler RC. Epidemiology of women and depression. J Affec Disord. 2003;74:5-13.

30. King AC, Oka RK, Young DR. Ambulatory blood pressure and heart 
rate responses to the stress of work and caregiving in older women. J Gerontol. 1994;49:239-45.

31. Lee S, Colditz GA, Berkman LF, Kawachi I. Caregiving and risk of coronary heart disease in U.S. women: a prospective study. Am J Prev Med. 2003;24:113-9.

32. Vitaliano PP, Russo J, Bailey SL, Young HM, McCann BS. Psychosocial factors associated with cardiovascular reactivity in older adults. Psychosom Med. 1993;55:164-77.

33. Kiecolt-Glaser JK, Glaser R, Gravenstein S, Malarkey WB, Sheridan J. Chronic stress alters the immune response to influenza virus vaccine in older adults. Proc Natl Acad Sci U S A. 1996;93:3043-7.
34. Glaser R, Kiecolt-Glaser JK. Chronic stress modulates the virus-specific immune response to latent herpes simplex virus type 1. Ann Behav Med. 1997;19:78-82.

35. Kiecolt-Glaser JK, Marucha PT, Malarkey WB, Mercado AM, Glaser R. Slowing of wound healing by psychological stress. Lancet. 1995;346:1194-6.

36. Kiecolt-Glaser JK, Dura JR, Speicher CE, Trask OJ, Glaser R. Spousal caregivers of dementia victims: longitudinal changes in immunity and health. Psychosom Med. 1991;53:345-62.

37. Schulz R, Beach SR. Caregiving as a risk factor for mortality: the Caregiver Health Effects Study. JAMA. 1999;282:2215-9. 